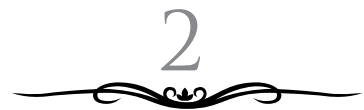

\title{
PERANAN PERPUSTAKAAN DALAM MENINGKATKAN KUALITAS PERGURUAN TINGGI (Konstruksi Pelayanan, Strategi, dan Citra Perpustakaan)
}

\author{
Junaeti dan Agus Arwani \\ UPT Perpustakaan STAIN Pekalongan \\ net_manise@yahoo.com,agus.arwani@stain-pekalongan.ac.id
}

\begin{abstract}
In an effort to support the implementation of universities, universities need to be supported by a set of facilities and infrastructure. One of the basic and essential facilities are available and a library with adequate service. Libraries who is a supporter of university should be able to play an active role to support the task of universities. The library is a facility or providing a means of readingmaterials. The purpose of the library itself, especially the college library is to provide information services for learning, research, and community service in order to implement the Tri Dharma College tow. Libraries have a very significant role in the institutions, especially institutions that shelter the college library. With good management, the library will have a positive impact for users it serves. Availability of a wide range of services and knowledge in the college library, will give the user a chance to utilize and develop knowledge independently. Repair image of the library as an institution of professional higher education and provide information services to the campus community will open up the minds of them, that the library can be used as an alternative means that are used to study independently.
\end{abstract}

Keywords: The Role, Libraries, Universities. 


\begin{abstract}
Abstrak
Dalam upaya mendukung terlaksananya perguruan tinggi, lembaga perguruan tinggi perlu ditunjang oleh seperangkat fasilitas serta prasarana. Salah satu fasilitas pokok dan esensial adalah tersedianya perpustakaan dengan koleksi dan layanan yang memadai. Perpustakaan yang merupakan pendukung dari perguruan tinggi harus dapat berperan aktif menunjang tugas perguruan tinggi. Perpustakaan adalah fasilitas atau tempat menyediakan sarana bahan bacaan. Tujuan dari perpustakaan sendiri, khususnya perpustakaan perguruan tinggi adalah memberikan layanan informasi untuk kegiatan belajar, penelitian, dan pengabdian masyarakat dalam rangka melaksanakan Tri Dharma Perguruan Tingg. Perpustakaan mempunyai peran yang sangat berarti dalam institusi lembaga yang menaunginya khususnya perpustakaan perguruan tinggi. Dengan adanya pengelolaan yang baik, perpustakaan akan memberikan dampak yang positif bagi pemakai yang dilayaninya. Ketersediaan berbagai macam layanan dan pengetahuan di perpustakaan perguruan tinggi, akan memberikan kesempatan pemakai untuk dapat memanfaatkan dan mengembangkan pengetahuan secara mandiri. Perbaikan citra perpustakaan perguruan tinggi sebagai institusi profesional dan memberikan layanan informasi bagi komunitas kampus akan membuka cakrawala berpikir mereka, bahwa perpustakaan dapat dijadikan sebagai sarana alternatif yang digunakan untuk belajar secara mandiri.
\end{abstract}

Kata Kunci: Peranan, Perpustakaan, Perguruan Tinggi.

\title{
A. Pendahuluan
}

Dalam menghadapi era globalisasi, tantangan yang dihadapi perguruan tinggi di Indonesia, semakin besar dan kompleks, baik yang ditimbulkan oleh dinamika internal maupun eksternal. Perguruan tinggi harus terus berupaya mewujudkan visi, misi dan tujuannya dengan tetap berpijak pada akar budaya yang $a^{1}{ }^{1}$. Perpustakaan adalah mencakup suatu ruangan, bagian dari

${ }^{1}$ Joane Marshall, Linda Moulton, dan Roberta Piccoli, "Kompetensi 
gedung/ bangunan atau gedung tersendiri yang berisi bukubuku koleksi, yang diatur dan disusun demikian rupa, sehingga mudah untuk dicari dan dipergunakan apabila sewaktu-waktu diperlukan oleh pembaca ${ }^{2}$. Tidak dapat dipungkiri lagi bahwa perpustakaan adalah salah satu basis penyangga peradaban bangsa.

Perpustakaan memiliki peranan strategis dalam mencerdaskan kehidupan anak bangsa, baik di negara maju maupun negara berkembang. Keberadaan perpustakaan adalah keniscayaan dalam kemajuan peradaban dan kebudayaan ummat manusia. Perpustakaan merupakan pusat sumber informasi, ilmu pengetahuan, teknologi, kesenian, dan kebudayaan. Perpustakaan memiliki peranan strategis dalam mencerdaskan kehidupan anak bangsa, baik di negara maju maupun negara berkembang. Keberadaan perpustakaan adalah keniscayaan dalam kemajuan peradaban dan kebudayaan ummat manusia. Perpustakaan merupakan pusat sumber informasi, ilmu pengetahuan, teknologi, kesenian, dan kebudayaan. Perpustakaan bisa berfungsi sebagai wahana pendidikan, penelitian, pelestarian, informasi, dan rekreasi untuk meningkatkan kecerdasan dan keberdayaan bangsa. Kebijakan untuk memajukan dunia perpustakaan di Indonesia dinilai merupakan opsi yang paling realistis sebagai wahana belajar sepanjang hayat mengembangkan potensi masyarakat agar menjadi manusia yang beriman dan bertakwa kepada Tuhan Yang Maha Esa, berakhlak mulia, sehat, berilmu, cakap, kreatif, mandiri, dan menjadi warga negara yang demokratis serta bertanggungjawab dalam mendukung penyelenggaraan pendidikan Nasional. Sebuah bangsa bisa dinilai maju atau tidak dalam peradaban dan kebudayaannya seiring dengan tingkat kecerdasan warga negaranya dalam menguasai ilmu pengetahuan dan teknologi.

Pustakawan Khusus di Abad Ke-21", BACA, Jurnal Dokumentasi dan Informasi, Vol. 27, Februari 2003, hlm. 2.

${ }^{2}$ Sutarno N.S., Perpustakaan dan Masyarakat (Jakarta: Sagung Seto, 2006), hlm. 11. 
Tulisan ini akan menyoroti peran perpustakaan dalam meningkatkan mutu Perguruan Tinggi. Haliinikarena perpustakaan merupakan upaya untuk memelihara dan meningkatkan efisiensi dan efektifitas proses belajar-mengajar. Perpustakaan yang terorganisasi secara baik dan sistematis, secara langsung atau pun tidak langsung dapat memberikan kemudahan bagi proses belajar mengajar di sekolah atau perguruan tinggi tempat perpustakaan tersebut berada. Halini, terkait dengan kemajuan bidang pendidikan dan dengan adanya perbaikan metode belajar-mengajar yang dirasakan tidak bisa dipisahkan dari masalah penyediaan fasilitas dan sarana pendidikan ${ }^{3}$.

\section{B. Pembahasan}

\section{Peran Perpustakaan}

Dahulu perpustakaan masih menggunakan kartu katalog, tetapi seiring dengan perkembangan zaman maka koleksi perpustakaan semakin banyak dan kompleks sehingga diperlukan sistem untuk mengaturnya. Disini Teknologi Informasi berperan dalam melakukannya dengan cara membangun pangkalan data. Tujuan dari pangkalan data adalah untuk mencatat (record) data dari semua koleksi yang dimiliki dan kemudian mengorganisirnya dengan menggunakan kaidah-kaidah ilmu perpustakaan. (Klasifikasi, katalogisasi, pengindeksan dan lain-lain) Pada sistem manual, proses ini dilakukan dengan menggunakan bantuan media kertas atau buku (Kartu katalog atau bibliografi). Tapi dengan proses manual ini pengelolaah data akan efektif jika data yang tersedia masih sedikit, akan tetapi jika data sudah banyak maka keefektifitasan sistem manual tidak berlaku karena akan timbul kesulitan dalam melakukan penelusuran data dengan cepat.

Revolusi teknologi informasi sangat berperan dalam dunia perpustakaan. Perpustakaan yang dulunya pasif menjadi lebih agresif dalam berinteraksi dengan penggunanya. Perkembangan

${ }^{3}$ Dian Sinaga, Mengelola Perpustakaan Sekolah (Jakarta: Kreasi Media Utama, 2007), hlm. 15. 
teknologi informasi yang terjadi sepuluh tahun terakhir sangatlah pesat fenomena ini melebihi satu abad sebelumnya. Hampir semua aspek kehidupan telah dimasuki oleh teknologi. Perkembangan teknologi memberi kemudahaan dan kecepatan dalam memperoleh informasi. Teknologi memberikan dimensi yang lebih luas. Teknologi juga membuka jendela wawasan kita akan kehidupan dan perkembangan suatu bangsa yang terpisah ribuan bahkan jutaan mil dari tempat kita berada. Perkembangan teknologi menuntut perubahan pola pikir kita. Perpustakaan yang dahulu mewajibkan pengunjung untuk meluangkan waktu pada jam sibuk untuk meminjam buku dan harus tepat waktu untuk mengembalikannya, dengan kemajuan teknologi informasi maka semuanya dapat teratasi. Peminjaman buku tidak lagi mewajibkan anggota/pengguna untuk datang pada jam kerja, karena dimanapun dan kapanpun mereka membutuhkan literature mereka dapat meminjamnya dan tidak perlu takut untuk didenda karena lupa mengembalikannya karena dalam mengembalikan literature/ koleksi (file-file dokumen yang berwujud digital) pengguna tidak harus mendatangi perpustakaan melainkan cukup melakukan transaksi di depan komputer yang telah terhubung ke internet dan pengguna tinggal mengunjungi situs dari perpustakaan itu untuk melakukan transaksi pengembalian koleksi. Teknologi akan melakukannya dengan sendirinya. Penggunaan teknologi akan mempermudah proses memasukkan data pada perangkat lunak pengolah data seperti: CDS/ISIS (WINISIS), SIPUS, Siprus, Senayan, Athenium Light, dan lain-lain. Perangkat lunak ini akan membantu kita untuk mengelola pangkalan data ini menjadi lebih mudah karena proses pengindeksan akan dilakukan secara otomatis dan proses penelusuran informasi akan dapat dilakukan dengan cepat dan akurat karena perangkat lunak ini akan menampilkan semua data sesuai kriteria yang kita tentukan. Saat ini bermunculan software-software perpustakaan baik yang berbayar maupun gratis. Software-software ini sangat membantu dalam penerapan otomasi perpustakaan. Penerapan otomasi perpustakaan harus didukung dengan software perpustakaan dan akan lebih efisien jika didukung dengan adanya internet. Internet merupakan sebuah jaringan antar 
komputer yang memungkinkan kita untuk berkomunikasi satu dengan lain tanpa mengenal batas-batas institusi, negara, bangsa, ras, dan birokrasi.

Otomasi Perpustakaan adalah sebuah sebuah proses pengelolaan perpustakaan dengan menggunakan bantuan teknologi informasi (TI). Dengan bantuan teknologi informasi maka beberapa pekerjaan manual dapat dipercepat dan diefisienkan. Selain itu proses pengolahan data koleksi menjadi lebih akurat dan cepat untuk ditelusur kembali. Dengan demikian para pustakawan dapat menggunakan waktu lebihnya untuk mengurusi pengembangan perpustakaan karena beberapa pekerjaan yang bersifat berulang (repetable) sudah diambil alih oleh komputer. Otomasi Perpustakaan bukanlah hal yang baru lagi dikalangan dunia perpustakaan. Konsep dan implementasinya sudah dilakukan sejak lama, namun di indonesia baru populer baru-baru ini setelah perkembangan Teknologi Informasi di Indonesia mulai berkembang pesat.. Berdasarkan penjabaran diatas dapat disimpulkan bahwa Otomasi perpustakaan (Library Automation) adalah pemanfaatan TI untuk kegiatan-kegiatan perpustakaan meliputi: pengadaan, pengolahan, penyimpanan dan menyebar luaskan informasi) dan mengubah sistem perpustakaan manual menjadi sistem perpustakaan terkomputerisasi ${ }^{4}$. Sebuah perpustakaan yang hendak menjalankan proses otomasi perpustakaan maka harus ada sebuah perangkat lunak sebagai alat bantu. Perangkat lunak ini mutlak keberadaannya karena digunakan sebagai alat pembantu mengefisienkan dan mengefektifkan proses.

Peran perpustakaan di era generasi millennial dituntut untuk lebih aktif dalam memberikan layanan informasi yang dibutuhkan penggunanya. Dalam memberikan layanan kepada pengguna, perpustakaan harus mengacu pada efisiensi dan efektifitas waktu. Sehingga pengguna merasa terpuaskan dengan layanan yang ada. Sebagai contoh, ketika pengguna menginginkan sebuah informasi yang berkaitan dengan koleksi perpustakaan

${ }^{4}$ Sulistiyo Basuki, Pengantar Ilmu Perpustakaan (Jakarta: Gramedia, 1991), hlm. 35 . 
(dalam hal ini dapat berupa buku maupun file-file dokumen), Pengguna bisa menanyakan ke perpustakaan tanpa harus datang ke perpustakaan melainkan cukup dengan cara memanfaatkan layanan telpon, sms, chatting, e-mail, dll yang disediakan oleh perpustakaan. Disini pustakawan dituntut untuk berperan aktif dalam melayani kebutuhan penggunanya.

Generasi millennial adalah sebuah generasi dimana mereka berperilaku sebagai seseorang yang haus akan ilmu. Selalu menanyakan pertanyaan setelah pertanyaan. Generasi millennial sangat familier dalam menggunakan TI, mereka sangat bergantung pada teknologi. Saat ini perkembangan Teknologi Informasi dan komunikasi berkembangan sangat pesat, dahulu jika ingin mengakses internet kita harus ke warnet atau menggunakan komputer yang terhubung dengan internet. Sekarang kita dapat mengakses layanan internet melalui Handphone (HP)/mobile. Kemudahan-kemudahan inilah yang memunculkan istilah "Dunia dalam genggaman", karena segala informasi dapat diakses dengan menggunakan HP dimanapun dan kapanpun kita membutuhkan informasi. Kemajuan-kemajuan teknologi ini seharusnya dapat dimanfaatkan oleh perpustakaan dalam meningkatkan layanannya. Sehingga dapat memacu perkembangan "perpustakaan/ilmu dalam genggaman". Era generasi millennial merupakan era dimana setiap kegiatan apapun harus didukung oleh teknologi, sehingga mau tidak mau, suka tidak suka perpustakaan harus bermetamorfosa dalam perkembangan teknologi ini. Disinilah peran pustakawan sangat dibutuhkan, dalam transisi perpustakaan manual ke perpustakaan otomasi yang kemudian menuju perpustakaan digital.

Fenomena perpustakaan digital baru-baru ini menjadi trend dikalangan dunia perpustakaan di Indonesia. Perpustakaan yang dulunya masih menggunakan sistem otomasi perpustakaan berbasis desktop berbondong-bondong beralih menjadi sistem otomasi perpustakaan berbasis web. Keunggulan sistem ini adalah dapat diakses dimanapun dan kapanpun oleh anggota perpustakaan karena sistem ini menggunakan jaringan internet untuk menunjang operasionalnya. Sistem inilah yang dianggap 
paling cocok di era generasi millennial, mereka dapat memenuhi kebutuhan akan informasi dan koleksi perpustakaan dengan kemudahan dan kecepatan yang memadahi. Kelebihan ini akan tidak berarti sama sekali jika pustakawan yang notabennya sebagai pengelola tidak dapat memaksimalkan perannya sebagai administrator. Pembangunan software perpustakaan yang berbasis web ini tentunya harus mengacu pada visi misi lembaga induknya, misalkan lembaga induk perpustakaan ini adalah universitas maka perpustakaan harus dapat mendukung visi dan misi universitas yang menaunginya. Pendanaan, infrastruktur, dan sumber daya manusia dalam hal ini pustakawan, harus disiapkan sedemikian rupa sehingga sistem ini dapat berjalan sesuai rencana.

\section{Pelayanan Perpustkaan Sebuah Realitas Peningkatan Kualitas Perguruan Tinggi}

Kualitas pelayanan menjadi ukuran manfaat tidaknya suatu perpustakaan bagi pemakainya. Definisi mengenai kualitas suatu pelayanan memang tidak dapat diterima secara universal. Menurut Kotler dalam Tjiptono, pelayanan (jasa) didefinisikan sebagai setiap tindakan atau perbuatan yang dapat ditawarkan oleh suatu pihak lain yang pada dasarnya bersifat intangible (tidak berwujud fisik) dan tidak menghasilkan kepemilikan sesuatu. Sebagaimana telah dijelaskan di atas, layanan perpustakaan tidak berorientasi kepada hasil fisik, meskipun demikian pustakawan tetap diminta untuk kreatif dalam menyajikan kemasan informasi yang diberikan kepada pemakai ${ }^{5}$.

Pelayanan (jasa) adalah setiap tindakan atau aktivitas yang pada dasarnya tidak berujud fisik yang ditawarkan dari suatu pihak kepada pihak yang lain sehingga mendatangkan kepuasan atau kemanfaatan. Pengertian pelayanan yang dimaksud adalah pelayanan kepada masyarakat umum atau pelayanan pemakai perpustakaan. Pelayanan mempunyai sifat universal, artinyaberlaku terhadap siapa saja yang menginginkannya. Oleh karenanya,

\footnotetext{
${ }^{5}$ Fandy Tjiptono, Strategi Pemasaran. (Yogyakarta: Andi Offset, 2001),
} hlm. 6 . 
pelayanan yang memuaskan pemakai memegang peranan penting agarperpustakaan dapat eksis. Lebih lanjut Moenir mengungkapkan perwujudan pelayanan yang didambakan adalah ${ }^{6}$ :

a. Adanya kemudahan dalam pengurusan kepentingan dengan pelayanan yang cepat dalam arti tanpa hambatan yang kadang dibuat-buat,

b. Memperoleh pelayanan secara wajar tanpa gerutu atau sindiran yang mengarah kepada permintaan sesuatu, baik dengan alasan untuk dinas maupun kesejahteraan,

c. Mendapatkan perlakuan yang sama dalam pelayanan terhadap kepentingan yang sama, tertib dan tidak pandang bulu,

d. Pelayanan yang jujur dan terus terang.

Pelayanan perpustakaan sudah selayaknya berorientasi pada pemakai, sehingga kepuasan pemakai selalu diutamakan dalam rangka meningkatkan hubungan antara pelanggan dan pengelola. Setiap pelayanan terdapat berbagai faktor yang mempengaruhi. Faktor-faktor tersebut bisa berasal dari dalam maupun dari luar sistem penyelenggaraan. Faktor yang mempengaruhi tesebut di antaranya:

a. Faktor kesadaran para pejabat serta petugas yang berkecimpung dalam pelayanan,

b. Aturan kerja yang melandasi kerja pelayanan,

c. Pendapatan yang dapat memenuhi kebutuhan hidup minimal,

d. Faktor ketrampilan petugas,

e. Faktor sarana dalam pelaksanaan tugas pelayanan,

f. Faktor organisasi yang merupakan alat serta sistem yang memungkinkan berjalannya mekanisme kegiatan pelayanan $^{7}$.

${ }^{6}$ A.S. Moenir, Manajemen Pelayanan Umum di Indonesia (Jakarta: Bumi Aksara, 1995), hlm. 410.

${ }^{7}$ Ibid., hlm. 88. 
Layanan perpustakaan, antara lain: (a) Peminjaman: menyusun peraturan peminjaman, merancang formulir dan catatan, mengawasi koleksi tendon, menyiapkan laporan statistic,menangani kebutuhan pemustaka, dan lain-lain. (b) Layanan rujukan, terdiri dari: menentukan kebijakan layanan rujukan, menjawab pertanyaan, pembimbingan mengenai cara perujukan dan menggunakan sumber rujukan, menghimpun bibliografi, membuat indeks khusus, memberikan informasi kepada pemustaka tentang buku yang berhubungan dengan minatnya, dan lain-lain. (c) Perawatan bahan perpustakaan: menentukan cara dan teknikpengawetan, menentukan kebijakan penjilidan, penambahan dan penghapusan, merencanakan pengaturan rak, mengawasi prosedur penyimpanan buku dalam rak, dan lain-lain. (d) Jaringan kerja sama: turut serta dalam pengkatalogan bersama,, mengawasi silang layan, mengawasi keterlibatan dalam penyusunan catalog induk dan pusat bibliografi, mengesahkan data bibliografi untuk silang layan, dan lain-lain. (e) Pengembangan: menyusun rencana perpustakaan secara menyeluruh, merencanakan dan memulai kegiatan baru, menentukan cara mencatat, membuat statistic dan formulir yang diperlukan, membuat analisis pekerjaan, melatih dan mengajar jaryawan baru, membimbing peserta magang, melatih karyawan untuk meningkatkan kinerja dan pengetahuan, dan lain-lain. (f) Administrasi: merencanakan anggaran, memberikan arahan tentang pemeliharaan gedung dan pekarangan, menentukan bahan habis pakai, menyiapkan laporan, mengatur penempatan karyawan, meningkatkan kesejahteraan karyawan, dan lain- lain.

Menurut Mangkunegara kebutuhan dapat didefinisikan sebagai suatu kesenjangan atau pertentangan yang dialami antara suatu kenyataan dengan dorongan yang ada dalam diri ${ }^{8}$. Apabila konsumen kebutuhannya tidak terpenuhi, ia akan menunjukkan perilaku kecewa. Sebaliknya, jika kebutuhannya terpenuhi, konsumen akan memperlihatkan perilaku yang gembira sebagai manifestasi rasa puasnya.

${ }^{8}$ A.A. Mangkunegara dan Anwar Prabu, Perilaku Konsumen, Edisi Revisi (Bandung: Refika Aditama, 2005). 
Dalam usaha memberikan layanan yang berkualitas, seperti yang dikutip Armansyah (1998), perpustakaan perguruan tinggi menghadapi berbagai masalah yang terungkap dari hasil penelitian Higher Education Development Support (HEDS) - USAID Jakarta (1995), masalah-masalah tersebut meliputi':

a. Kurangnya dana yang tersedia.

b. Tenaga profesional ditugaskan untuk mengerjakan pekerjaan yang bersifat teknis.

c. Keadaan staf:

1) Kurang membutuhkan dan kurang merasakan manfaat teknologi informasi;

2) Kurang berpengalaman di bidang layanan informasi;

3) Rendahnya motivasi, kurangnya visi, kurang dalam bersikap, rendahnya semangat dalam melayani pemakai.

a. Sebagian besar staf bukan berlatar belakang pendidikan ilmu perpustakaan.

b. Kurangnya pendidikan dan pelatihan mengenai kepemimpinan dan keterampilan manajerial.

c. Kurangnya kebijakan mengenai kebijakan pengembangan koleksi, kebijakan pengadaaan bahan pustaka dan prosedurnya.

d. Kepuasan pemakai sangat rendah, kurang lengkapnya fasilitas perpustakaan dan tidak tersedianya umpan balik dari pemakai.

e. Otomatisasi perpustakaan tidak didukung baik oleh keterampilan maupun dana.

9 Cut Armansyah, "Penerapan Total Quality Management dalam Manajemen Perpustakaan: Survey pada Beberapa Perpustakaan di Jakarta", Tesis, Pascasarjana Universitas Indonesia, 1998. 


\section{Konstruksi Strategi Perpustakaan dalam Peningkatan Kualitas Perguruan Tinggi}

Misi perpustakaan adalah menyebarluaskan informasi kepada pemustaka yang membutuhkannya. Koleksi perpustakaan lengkap dan bagus, tempatnya nyaman, namun sepi pengunjung. Tentunya ini ada penyebabnya, salah satunya adalah kurangnya promosi. Maka peran pustakawan untuk memasarkan produknya untuk memuaskan konsumen, maka sangat diperlukan promosi. Dalam hal mempromosikan perpustakaan, maka pustakawan perlu mengenal perilaku konsumen.

Perilaku konsumen dapat didefinisikan sebagai proses pengambilan keputusan dan aktivitas individu secara fisik yang dilibatkan dalam proses mengevaluasi, memperoleh, menggunakan atau dapat mempergunakan barang-barang dan jasa ${ }^{10}$. Perilaku konsumen adalah suatu proses yang terdiri dari beberapa tahap, yaitu:

a. Tahap perolehan (acquisition): mencari (searching) dan membeli (purchasing),

b. Tahap konsumsi(consumption): menggunakan (using), dan mengevaluasi (evaluating),

c. Tahap tindakan pasca beli (disposition): apa yang dilakukan oleh konsumen setelah produk itu digunakan atau dikonsumsi ${ }^{11}$.

Dari kedua definisi tersebut, dapat diberikan komentar bahwa mula-mula konsumen melakukan pencarian barang/jasa yang dibutuhkan. Dalam hal pemustaka mencari (searching) dapat melalui alat bantu penelusuran (catalog perpustakaan) atau langsung menuju ke rak dimana buku tersimpan. Ketersediaan katalog yang memadai dan susunan buku di rak secara teratur akan mempercepat proses temu kembali informasi. Jika hal ini terjadi maka kebutuhan pemustaka terpenuhi dan kepuasan akan

${ }^{10}$ A.A. Mangkunegara dan Anwar Prabu, Perilaku Konsumen, Edisi Revisi (Bandung: Refika Aditama, 2005).

${ }^{11}$ Prasetijo, Ristiyanti, dan Ihalauw, Perilaku Konsumen (Yogyakarta: Andi, 2005), hlm. 15-20. 
diperolehnya. Tahap purchasing adalah keputusan yang diambil oleh pemustaka untuk meminjam koleksi dari berbagai pencarian yang dilakukan sebelumnya.

Tahap menggunakan (Using), mengevaluasi (evaluating) dan pasca beli/pinjam (disposition) adalah tahapan dimana pemustaka memanfaatkan atasinfomasiyang diperolehnya. Pemanfaatan informasi tersebut tentunya akan berdampak pada perilku pemakainya, tergantung untuk apa pemustaka meminjam/ mencari informasi tersebut. Apabila tujuan pinjam/ memperoleh informasi untuk keperluan studi, pengajaran, dan atau penelitian maka pemustaka akan merasa terpenuhi kebutuhannya itu. Ada beberapa hal yang perlu diperhatikan bagi para pustakawan, dalam hal promosi terhadap produk jasa yang milikinya, antara lain:

a. Segmentasi pasar perpustakaan. "Segmentasi pasar adalah usaha pemisahan pasar pada kelompok-kelompok pembeli menurut jenis-jenis produk tertentu dan memerlukan bauran pemasaran sendiri"'12. Dalam hal ini perpustakaan dapat mengelompokkan koleksinya berdasarkan pelanggan yang dilayaninya. Misalnya pada perpustakaan umum, dapat mengelompokkan koleksinya berdasarkan kebutuhan tingkat pendidikan (SD, SMP, SMA, Perguruan Tinggi). Dapat pula dikelompokkan berdasarkan profesi/pekerjaan para pelanggan (petani, pedagang, seniman, karyawan, dan lain-lain). Atau dapat juga dapat mengelompokkan berdasarkan subjeknya. Perpustakaan Perguruan Tinggi dalam mengelompokkan koleksi dapat berdasarkan fakultas atau per program studi. Segementasi pasar adalah mengidentifikasi konsumen dengan kebutuhan yang sama dan memenuhi kebutuhan-kebutuhan itu dengan menawarkan produk (koleksi perpustakaan). Segementasi pasar bermanfaat untuk: (1) Dengan cepat dapat mendeteksi kecenderungan perubahan kebutuhan para pemustaka, (2) Merencanakan ketersediaan koleksi sesuai

${ }^{12}$ A.A. Mangkunegara dan Anwar Prabu, Perilaku Konsumen, Edisi Revisi (Bandung: Refika Aditama, 2005). 
dengan permintaan pemustaka, dan (3) Menentukan jenis promosi yang akan dilakukan.

b. Mempelajari perilaku konsumen. Analisis konsumen memainkan peranan penting dalam pengembangan kebijakan public. Misalnya analisis untuk meningkatkan layanan perpustakaan keliling di daerah kepulauan, maka yang diperlukan adalah alat transportasi yang sesuai dengan wilayah itu (yaitu dengan perahu). Apabila daerah yang dilayani berupa bukit dan pegunungan sehingga untuk perjalanan darat dan laut sulit, maka yang diperlukan adalah alat transportasi udara berupa helicopter dan atau yang sejenisnya.

c. Promosi Perpustakaan. Promosi dimaksudkan untuk lebih mengenalkan perpustakaan kepada masyarakat tentang kegiatan perpustakaan dengan berbagai sumber daya yang dimilikinya. Hal-hal yang dapat dipromosikan kepada masyarakat adalah tentang berbagai koleksi yang ada, pentingnya masyarakat gemar membaca, mengenalkan adanya teknologi informasi (misalnya dengan memperkenalkan internet dengan berbagai kelebihan dan keunikannya), dan lain-lain. Banyak hal baru di perpustakaan untuk meningkatkan layanannya, tetapi kurang dikenal oleh masyarakat.

d. Teknik Pendekatan untuk Mempengaruhi Pemustaka. Teknik Pendekatan Stimulus Respon, adalah merupakan teknik menyampaikan ide-ide atau pengetahuan tentang koleksi kepada pemustaka agar pemustaka tertarik atau termotivasi untuk mengambil keputusan meminjam koleksi-koleksi yang disampaikan itu. Dengan kata lain perpustakaan atau pustakawan memberikan stimulus berupa koleksi-koleksi yang ada di perpustakaan kemudian diharapkan pemustaka dapat meresponnya secara positif. Misalnya seorang pemustaka menanyakan tentang buku Psikologi Sosial, maka pustakawan dapat memberikan informasi tentang judul, pengarang, garis besar isi pada setiap judul/pengarang, tahun penerbitan, dan buku yang 
diacu oleh dosen untuk mengajar. Kemudian pemustaka diarahkan untuk meminjam diantara alternative yang cenderung mendapat perhatian atau tanggapan positif dari pemustaka tersebut. Dengan demikian si pemustaka akan lebih mudah mengambil keputusan.

Teknik Pendekatan Humanistik. Teknik ini merupakan teknik pendekatan yang bersifat manusiawi. Dalam teknik ini keputusan meminjam sepenuhnya diserahkan kepada pemustaka yang bersangkutan. Perpustakaan atau pustakawan hanya lebih bersifat menyediakan berbagai koleksi dengan memberikan informasi tentang manfaat, kelebihan dan kekurangan yang terdapat pada masing-masing koleksi yang tersedia.

Teknik Pendekatan Gabungan antara Stimulus-Respon dan Humanistik; Teknik ini merupakan teknik pendekatan dari hasil kombinasi antara teknik stimulus-respon dan teknik humanistic. Perpustakaan atau Pustakawan dalam menghadpi pemustaka lebih bersifat mengkondisikan perilaku yang memungkinkan pemustaka termotivasi untuk meminjam/menggunakan, namun keputusan meminjam/membaca sepenuhnya diserahkan kepada pemustaka. Misalnya koleksi yang disusun dengan berbagai bentuk yan menarik pemustaka, display pustaka disusun teratur yang memungkinkan menjadi pusat perhatian pemustaka.

Perpustakaan berusaha memberikan layanan yang berkualitas dan didukung dengan pendekatan pelayanan pengguna yang kuat, perpustakaan akan semakin dihargai oleh pemakai. Untuk meningkatkan kualitas pelayanan pengguna ini menurut Priyanto, perpustakaan perlu berusaha untuk:

a. Menjaga konsumen agar tetap kembali setelah layanan pertamanya.

b. Menarik pemakai-pemakai baru.

c. Menghilangkan pandangan-pandanganyangkelirutentang metoda, prosedur, image dan layanan perpustakaan.

d. Mampu membiayai operasional layanan yang berkualitas, baik dengan dana bantuan maupun dana yang diperoleh dari layanan-layanan fee- based tertentu. 
e. Meningkatkan moral dan kinerja seluruh staf perpustakaan dengan bekerja sama guna memenuhi kebutuhan pemakai dan guna memperoleh feedback positif dari pemakai atas layanan yang diberikan oleh perpustakaan ${ }^{13}$.

\section{Citra Perpustakaan Sebuah Konstruksi Peningkatan Kualitas Perguruan Tinggi}

Citra merupakan kesan imajinatif yang terbentuk dalam benak publik dalam rentang waktu tertentu dan terbentuk oleh keseluruhan informasi tentang diri kita yang sampai ke publik ${ }^{14}$. Sedangkan citra suatu perpustakaan dapat dikatakan sebagai suatu pandangan yang diberikan oleh masyarakat tentang sebuah institusi perpustakaan. Dalam institusi perpustakaan yang merupakan organisasi profesional dan selayaknya diurus oleh pustakawan yang juga profesional, maka pustakawan harus mampu memperoleh kesan (image) dari pemustaka sebagai kesan yang baik. Kesan baik yang diciptakan oleh pustakawan dalam memberikan pelayanan kepada pemustaka merupakan wujud komitmen pustakawan dalam menjalankan profesinya sebagai seorang pustakawan dalam rangka menjalankan tugas kepustakawanannya. Kesan yang baik dapat diciptakan dengan memberikan nilai lebih dalam melakukan pelayanan kepada pemustaka. Wujud nyata dalam melakukan pelayanan kepada pemustaka dapat dilakukan oleh pustakawan dengan memberikan pelayanan yang optimal sesuai kebutuhan pemustaka.

Untuk mengimplementasikan kesan pustakawan yang baik, maka pustakawan dapat melakukan berbagai cara, antara lain: pustakawan harus mempunyai sikap dan perilaku yang baik dan berorientasi kepada kebutuhan pelanggan dengan memberikan hal-hal yang positif sesuai dengan

13 Ida Fajar Priyanto, "Layanan Pemakai yang Berkualitas: Suatu Gagasan”, Media Informasi, XI, Maret 1997.

14 Hoeroestijati, "Peran Pustakawan dalam Pembentukan Citra Perpustakan”, http://pemasaran.wikispace.com/file/view/ makalah+manajemen+pemasaran.Pdf, diakses pada 28 Maret 2016, hlm. 3. 
standar yang telah ditetapkan oleh perpustakaan, disamping itu perlunya pemahaman diri pustakawan dalam memberikan kepuasan kepada pemustaka, bahwa pemustaka dianggap penting sehingga pustakawan akan menyadari betapa pemustaka merasa dihargai dan dipenuhi kebutuhanya.

Hal lain yang perlu jadi perhatian bagi pustakawan dalam meningkatkan citra yaitu pustakawan harus mampu membaca kebutuhan pemustaka. Pustakawan dalam menyediakan informasi kepada pemustaka harus sesuai dengan kebutuhan pemustaka. Hal itu bisa diukur berdasarkan dari indikator yang dibuat oleh pustakawan melalui penelitian tentang kepuasan pemustaka yang dilakukan secara rutin. Pustakawan juga harus meningkatkan kompetensinya dan keprofesionalitasnya guna meningkatkan kualitas kinerja di perpustakaan.

Keprofesionalitas pustakawan sangat tergantung dengan kemauan diri pribadi pustakawan dalam mengembangkan diri dan membangun citra diri (image branding) yang saat ini sudah menjadi keharusan bagi pustakawan agar pengakuan status profesi kepustakwanannya dinilai oleh masyarakat yang dilayaninya. Citra pustakwan sangat ditentukan oleh kinerja pustakawan. Dan kinerja sangat tergantung pada kompetensi atau kapasitas internal yang dimiliki, jadi untuk membangun citra pustakawan yang baik hal pertama yang harus dilakukan adalah memperbaiki kinerja dengan membentuk citra diri positif pustakawan. Dengan citra positif pustakawannya, maka citra perpustakaan akan meningkat dengan sendirinya.

Perpustakaan merupakan salah satu sarana pembelajaran dengan tujuan mencerdaskan bangsa mempunyai peranan penting sebagai jembatan menuju penguasaan ilmu pengetahuan yang sekaligus menjadikan perpustakaan sebagai tempat rekreasi yang menyenangkan dan mengasyikkan. Oleh karena itu perlu dibangun citra perpustakaan agar dapat berkembang dengan baik untuk memenuhi kebutuhan pengguna pada era globalisasi ini. Dengan membangun citra yang positif, keberadaan perpustakaan akan membawa dan mengembangkan citra institusinya. Dalam 
mengembangkan citra, perpustakaan berusaha meningkatkan layanan yang sesuai standar yang telah ditetapkan, khususnya perpustakaan perguruan tinggi.

Perpustakaan perguruan tinggi adalah perpustakaan yang melayani para mahasiswa, dosen, dan karyawan. Perpustakaan perguruan tinggi didirikan dengan tujuan untuk mendukung, memperlancar, dan meningkatkan kualitas pelaksanaan program Tri Dharma Perguruan Tinggi melalui pelayanan informasi kepada sivitas akademika yang dilayaninya ${ }^{15}$. Dalam pelayanan kepada masyarakat sivitas akademika, perpustakaan perguruan tinggi akan selalu meningkatkan kualitas layanan, maupun unsur pustakawannya. Oleh karena itu perpustakaan harus mampu memberikan citra yang positif agar selalu sukses dalam berinteraksi denngan masyarakat yang dilayaninya. Dengan Citra yang negatif, maka akan dapat memperlemah dan merusak strategi yang telah dibangun dengan susah payah oleh pustakawan. Sedangkan citra positif bisa didapat dengan mengkomunikasikan keunikan dan kualitas terbaik yang dimiliki perpustakaan kepada pemustakanya.

Perpustakaan perguruan tinggi yang merupakan jantung bagi kehidupan sivitas akademika, karena dengan adanya perpustakaan dapat diperoleh data maupun informasi yang dapat digunakan sebagai dasar pengambilan keputusan dan perencanaan serta dapat menyegarkan dan mengembangkan ilmu pengetahuan. Perpustakaan harus menjadi sarana interaktif dan menjadi tempat munculnya ide kreatif dalam berbagai hal baru yang dapat digali melalui sumber informasi yang disediakan oleh perpustakaan.

Dalam mengembangkan citra perpustakaan khususnya perpustakaan perguruan tinggi, perlu dilakukan strategi dengan 3 (tiga) pilar citra utama, yaitu: (a) membangun citra perpustakaan(building image), (b) meningkatkan citra pustakawan (librarian image), (c) mengembangkan perpustakaan

15 F.A. Wiranto, dkk., Perpustakaan Menjawab Tantangan Jaman (Semarang: Penerbit Universitas Katolik Soegijapranata bekerja sama dengan Perpustakaan Daerah Jawa Tengah, 1997). 
yang berbasis pada teknologi dan komunikasi atau information and communication technology (ICT based). Di samping hal tersebut, pustakawan juga harus memainkan berbagai peran, diantaranya sebagai edukator, manajer, administrator dana supervisor.

Menurut Pudjiono, dalam memenuhi kebutuhan meningkatkan citra perpustakaan perguruan tinggi, maka perpustakaan harus mempunyai strategi tiga pilar citra utama yang meliputi ${ }^{16}$ :

\section{1) Membangun citra perpustakaan (building image)}

Berdasarkan paradigm lama yang kita ketahui bahwa perpustakaan sering diartikan sebagai sebuah gedung tua, gelap, pengap, sepi, bahkan kalau saja perpustakaan diakui sebagai lembaga profesional dan tidak hanya dijadikan tempat untuk menumpuk buku, tempat yang tidak menarik untuk dikunjungi dan dianak tirikan oleh lingkungannya sendiri. Adanya paradigma tersebut, maka yang harus kita perhatikan adalah bagaimana membuat pengelola perpustakaan khususnya pustakawan agar pustakawan tidak semakin merasa minder karena profesinya belum diakui oleh masyarakat di sekelilingnya.

Oleh karena itu perlu adanya usaha agar tidak di pinggirkan atau dimarjinalkan, banyak perpustakaan perguruan tinggi yang mulai berbenah diri untuk meningkatkan citra perpustakaannya baik melalui pembenahan dari hal-hal yang sepele sampai pembenahan dalam skala besar. Skala kecil dengan membuat brand image perpustakaan agar dikenal orang, seperti melakukan promosi iklan dengan membuat leaflet, marchendaise yang berlogo perpustakaan, membuat acara bedah buku, pameran buku dan juga melakukan terobosan baru dengan merubah layout perpustakaan agar menarik, bahkan ada yang sampai melakukan perubahan nama dengan menggunakan istilah asing, maupun membuat slogan-slogan layanan.

${ }^{16}$ Pudjiono, "Membangun Citra: Perpustakaan Perguruan Tinggi di Indonesia Menuju Perpustakaan Bertaraf Internasional”, http://www.lib.ui.ac. id/files/pudjiono.pdf, diakses pada 28 Maret 2016, hlm. 3. 
Tidak kalah pentingnya adanya program-program layanan yang baru, seperti layanan pinjam antar perpustakaan perguruan tinggi, dimana pemakai dapat pinjam koleksi di perpustakaan lain, tetapi proses pinjamnya dengan petugas perpustakaan yang meminjamkan ke perpustakaan mitranya. Dengan upaya-upaya yang dilakukan perpustakaan tersebut, secara tidak langsung akan meningkatkan citra di mata masyarakat baik di lingkungan sendiri maupun eksternal lembaga perpustakaan, bahkan sampai tingkat nasional. Sedangkan peningkatan citra yang dilakukan perpustakaandalamjangkamenengahdenganpembangunan website perpustakaan dan melakukan renovasi dan penambahan ruangan sesuai kebutuhan pemustaka, misalnya adanya ruangan pribadi dengan fasilitas seperti internet, home theater dan layanan makan dan minuman. Tidak kalah penting yang perlu dikembangkan di perpustakaan yaitu sumber informasi yang dilayankan, baik koleksi buku, koleksi jurnal, koleksi e-journal maupun koleksi muatan lokal hasil karya sivitas akademika yang sekarang telah dialihmediakan menjadisoftcopy. Peningkatan citra yang harus dilakukan perpustakaan dalam skala besar yaitu dengan melakukan pembenahan gedung perpustakaan, karena banyak perpustakaan perguruan tinggi yang perpustakaannya masih bergabung dengan kantor pusat.

2) Meningkatkan citra pustakawan (librarian image)

Kita telah tahu, bahwa profesi pustakawan merupakan profesi yang belum populer dikalangan masyarakat kita, masih kalah populer dengan profesi insinyur, pengacara, bahkan artis sekalipun. Pilihan profesi pustakawan biasanya merupakan pilihan alternatif, dan tenaga pustakawan dipandang sebelah mata, tenaga pustakawan merupakan orang buangan. Hal itu semua menjadi penyebab buruknya citra terhadap profesi pustakawan. Walaupun yang telah kita ketahui, bahwa tenaga pustakawan merupakan jabatan karir dan jabatan fungsional yang telah diakui oleh pemerintah dengan terbitnya surat MENPAN nomor 132 tahun 2002. 
Dengan melihat permasalahan tersebut di atas mau tidak mau perpustakaan perguruan tinggi harus membekali tenaga pustakawannya untuk dapat bersikap profesional dalam memberikan pelayanannya. Dalam melakukan pelayanan kepada pemustaka, pustakawan harus membuat pemustaka merasa diistimewakan dan merasa penting karena dalam memberikan pelayanan terbaik kepada pemustaka harus berorientasi kepada kepentingan pemustaka, sehingga akan mampu memberikan kepuasan yang optimal ${ }^{17}$. Upaya dalam memberikan pelayanan yang terbaik dapat diwujudkan apabila pustakawan dapat menonjolkan kemampuan sikap, penampilan, perhatian dan tindakan, juga tanggungjawab yang baik.

Dalam meningkatkan kinerja dan kualitas layanan pustakawan dituntut bersikap profesional. Sikap profesionalisme tenaga pustakawan yang perlu diperhatikan adalah kepribadian pustakawan, kompetensi pustakawan, dan kecakapan pustakawan. Melihat kebutuhan tersebut, tuntutan bagi pustakawan adalah menjadi tenaga pustakawan ideal. Ukuran ideal yang disyaratkan yaitu apabila pustakawan memenuhi persyaratan, seperti yang tercantum dalam kode etik pustakawan ${ }^{18}$, yaitu:

a) Aspek profesional, meliputi hal mengenai pustakawan yang harus mempunyai pendidikan formal ilmu pengetahuan, pustakwan dituntut gemar membaca, terampil, kreatif, cerdas, tanggap, berwawasan luas, berorientasi kedepan, mampu menyerap ilmu, obyektif (berorientasi pada data), tetapi memerlukan disiplin ilmu tertentu di pihak lain, berwawasan lingkungan, mentaati etika profesi pustakwan, mempunyai motivasi tinggi, berkarya di bidang kepustakawanandan mampu melaksanakan penelitian dan penyuluhan.

${ }^{17}$ Suharto Abdul Majid, Customer Service Dalam Bisnis Jasa Transportasi (Jakarta: Rajawali Press, 2009).

${ }^{18}$ Rachman Hermawan, Etika kepustakawanan: Suatu Pendekatan terhadap Kode Etik Pustakawan Indonesia (Jakarta: Sagung Seto, 2006). 
b) Aspek kepribadian dan perilaku, meliputi pustakawan harus bertaqwa kepada Tuhan YME, bermoral pancasila, mempunyai tanggungjawab sosial dan kesetiakawanan, memiliki etos kerja yang tinggi, mandiri, loyalitas tinggi terhadap profesi, luwes, komunikasi, bersikap suka melayani, ramah dan simpatik, terbuka terhadap kritik dan saran, selalu siaga dan tanggap terhadap kemajuan dan perkembangan ilmu dan teknologi.

Dalam konteks pengembangan perpustakaan perguruan tinggi, yang perlu kita perhatikan adalah bagaimana pengembangan tenaga pustakwan untuk meningkatkan kualitas dalam pelayanan secara optimal. Sehingga untuk memenuhi kebutuhan itu, maka diperlukan adanya perilaku yang baik khususnya dalam berkomunikasi. Komunikasi yang perlu dilakukan oleh seorang pustakawan yaitu bagaimana agar sumber informasi dapat diakses sesuai kebutuhan pemakinya. Disamping itu adanya kecenderungan dari pustakawan itu sendiri, bahwa dalam memahami pekerjaannya kurang tanggap akan kebutuhan pemakainya. Bahkan seringkali pustakawan membuat citra buruk dengan mengesampingkan kebutuhan pemakai perpustakaan khususnya sivitas akademika yang dilayaninya. Untuk itu perlunya pustakawan berupaya mengembangkan kepribadian atau personalitas dalam melakukan pelayanan.

3) Perpustakaan berbasis teknologi innformasi dan komunikasi (ICT based)

Adanya perkembangan teknologi informasi dan komunikasi atau information and communication technology (ICT) telah membawa perubahan dalam berbagai bidang termasuk yang dialami oleh perpustakaan. Penggunaan teknologi informasi dan komunikasi (ICT based) sebagai sarana dalam meningkatkan kualitas layanan dan operasional perpustakaan tentu saja telah membawa perubahan yang sangat besar di perpustakaan. Bisa kita lihat perkembangan dan penerapan teknologi informasi dan komunikasi atauinformation and communication technology (ICT) dapat kita ukur dengan digunakannya teknologi ini sebagai 
system informasi manajemen perpustakaan dan perpustakaan digital (digital library).

Sistem informasi perpustakaan merupakan pengintegrasian antara bidang pekerjaan administrasi, pengadaan, inventarisasi, katalogisasi, pengolahan, sirkulasi, statistik, pengelolaan kartu anggota, dan lain-lain, dan sistem ini biasa kita sebut sebagai sebuah sistem otomasi perpustakaan. Dimana hampir semua perpustakaan sudah menerapkan sistem ini untuk memudahkan dalam melakukan pelayanan kepada pemakainya. Kemudahan yang kita dapatkan dalam sistem otomasi diperpustakaan dapat kita rasakan karena adanya kemudahan dalam melakukan pekerjaan di semua lini perpustakaan.

Sedangkan perpustakaan digital (digital library)yang dikatakan oleh Ismail Fahmi mengatakan, bahwa perpustakaan digital adalah sebuah sistem yang terdiri dari perangkat hardware dan software, koleksielektronik, stafpengelola, pengguna, organisasi, mekanisme kerja, serta layanan dengan memanfaatkan berbagai jenis teknologi informasi ${ }^{19}$. Menurut Zainal A. Hasibuan mengatakan, bahwa digital library atau sistem perpustakaa digital merupakan konsep menggunakan internet dan teknologi informasi dalam manajemen perpustakaan ${ }^{20}$.

Dalam pengembangan perpustakaan digital (digital library) bagi tenaga pengelola perpustakaan dapat membantu pekerjaan yang ada di perpustakaan melalui fungsi sistem otomasi perpustakaan, sehingga dalam proses pengelolaan perpustakaan menjadi lebih efektif dan efisien. Fungsi sistem otomasi perpustakaan menitikberatkan pada bagian pengontrolan sistem administrasi layanan secara online. Sedangkan bagi pengguna perpustakaan dapat membantu mencari sumber-sumber informasi

${ }^{19}$ Ismail Fahmi, "Inovasi Jaringan Perpustakaan Digital: Network of Networks NeONs”, Makalah Seminar dan Workshop Sehari Perpustakaan dan Informasi UniversitasMuhammadiyah Malang, 4 Oktober 2004.

${ }^{20}$ Zainal A. Hasibuan, "Pengembangan Perpustakaan Digital: Studi Kasus Perpustakaan Universitas Indonesia”, Makalah Pelatihan Pengelola Perpustakaan Perguruan Tinggi, Cisarua-Bogor, 17-18 Mei 2005. 
yang diinginkan dengan menggunakan OPAC yang dapat diakses melalui internet maupun intranet, sehingga dalam temu kembali informasi dapat dilakukan kapanpun dan dimanapun pemakai berada.

Implementasi dan pengembangan sebuah perpustakaan dari bentuk konvensional ke bentuk digital tentu saja memerlukan tenaga maupun biaya yang tidak sedikit, karena untuk melakukan proses digitalisasi sebuah dokumen dari bentuk hardcopy menjadi softcopy diperlukan beberapa tahap, antara lain tahap scanning yaitu proses merubah dari bentuk cetak menjadi bentuk softcopy, kemudian proses editing, proses ini adalah pengeditan mengedit data softcopy yang siap digunakan dan disajikan oleh pemakai perpustakaan. Proses pengeditan yang dilakukan tidak hanya mengedit teks saja tetapi data dalam bentuk softcopy tersebut, diberi pengamanan agar data tidak dirubah oleh pengguna perpustakaan.

Setelah koleksi digital siap dilayankan, maka yang harus disediakan adalah perangkat hardware berupa komputer sebagai sarana penyimpanan dan untukmelayanipemakai dalam mengakses koleksi digital. Koleksi digital dapat di akses melalui jaringan intranet maupun internet di perpustakaan. Untuk kebutuhan tersebut, maka perpustakaan tentu saja harus menyediakan jaringan baik intranet maupun internet sebagai media penelusuran sumber informasi koleksi digital.

Dengan dikembangkan perpustakaan berbasis pada teknologi informasi dan komunikasi atau information and communication technology (ICT) baik dalam sistem informasi manajemen perpustakaan maupun digital library, maka dapat memberikan layanan secara maksimal, kenyamanan, kemudahan kepada pemakai perpustakaan, kemudahan kepada tenaga pengelola perpustakaan baik dalam layanan maupun pengolahan dan sekaligus dalam menerapkan strategi-strategi pengembangan perpustakaan. Hal ini tentu saja akan meningkatkan citra perpustakaan dalam memberikan kemudahan fasilitas layanan yang disediakan perpustakaan terhadap pemakainya. 


\section{Simpulan}

Perpustakaan kini bukan lagi sebagai tempat gudang buku diartikan sebagai sebuah gedung tua, gelap, penggap dan sepi. Dalam upaya mendukung terlaksananya pendidikan tinggi, lembaga pendidikan tinggi perlu ditunjang oleh seperangkat fasilitas serta prasarana. Salah satu fasilitas pokok dan esensial adalah tersedianya perpustakaan dengan koleksi dan layanan yang memadai. Perpustakaan yang merupakan pendukung dari lembaga pendidikan tinggi harus dapat berperan aktif menunjang tugas perguruan tinggi. Namun kenyataannya peran perpustakaan ini belum optimal bagi banyak perguruan tinggi. Hal ini mungkin karena ketidaktahuan sivitas akademika dalam hal penggunaan perpustakaan, serta belum mantapnya sistem layanan di perpustakaan itu sendiri.

Perpustakaan mempunyai peran yang sangat berarti dalam institusi lembaga yang menaunginya khususnya perpustakaan perguruan tinggi. Dengan adanya pengelolaan yang baik, perpustakaan akan memberikan dampak yang positif bagi pemakai yang dilayaninya. Ketersediaan berbagai macam layanan dan pengetahuan di perpustakaan perguruan tinggi, akan memberikan kesempatan pemakai untuk dapat memanfaatkan dan mengembangkan pengetahuan secara mandiri. Paradigma perpustakaan perguruan tinggi saat ini yang telah menyediakan berbagai fasilitas dan akses sumber informasi yang disediakan secara online akan memberikan kemudahan pemakai perpustakaan dalam mengakses informasi yang dibutuhkan.

Perbaikan citra perpustakaan perguruan tinggi sebagai institusi profesional dan memberikan layanan informasi bagi komunitas kampus akan membuka cakrawala berpikir mereka, bahwa perpustakaan dapat dijadikan sebagai sarana alternatif yang digunakan untuk belajar secara mandiri. Beberapa pendekatan manajemen yang digunakan sebagai sarana untuk memperbaiki citra perpustakaan, maka digunakan strategi tiga pilar citra utama yaitu building image, librarian image, dan ICT based. Ketiga pilar 
tersebut memberikan alternatif berpikir untuk mengembangkan perpustakaan perguruan tinggi menjadi sebuah pusat informasi yang modern dan profesional. 


\section{DAFTAR PUSTAKA}

Armansyah, Cut, "Penerapan Total Quality Management dalam Manajemen Perpustakaan: Survey pada Beberapa Perpustakaan di Jakarta", Tesis, Pascasarjana Universitas Indonesia, 1998.

Fahmi, Ismail, "Inovasi Jaringan Perpustakaan Digital: Network of Networks NeONs”, Makalah Seminar dan Workshop Sehari

Perpustakaan dan Informasi Universitas Muhammadiyah, Malang 4 Oktober 2004.

Hasibuan, Zainal A., "Pengembangan Perpustakaan Digital: Studi Kasus Perpustakaan Universitas Indonesia”, Makalah Pelatihan Pengelola Perpustakaan Perguruan Tinggi, Cisarua-Bogor, 17-18 Mei 2005.

Hermawan, Rachman, Etika Kepustakawanan: Suatu Pendekatan Terhadap Kode Etik Pustakawan Indonesia. Jakarta: Sagung Seto, 2006.

Hoeroestijati, "Peran Pustakawan dalam Pembentukan Citra Perpustakan", http://pemasaran.wikispace.com/file/view/ makalah+manajemen+pemasaran.Pdf, diakses pada 28 Maret 2016.

Lasa, Manajemen Perpustakaan Sekolah, Yogyakarta: Pinus, 2007.

Majid, Suharto Abdul, Customer Service dalam Bisnis Jasa Transportasi, Jakarta: Rajawali Press, 2009.

Mangkunegara, A.A. dan Anwar Prabu, Perilaku Konsumen, Edisi Revisi, Bandung: Refika Aditama, 2005.

Marshall, Joane, Linda Moulton, dan Roberta Piccoli, "Kompetensi Pustakawan Khusus di Abad Ke-21", BACA, Jurnal Dokumentasi dan Informasi, Vol. 27, Tahun 2, 2003.

Moenir, A.S., Manajemen Pelayanan Umum di Indonesia, Jakarta: Bumi Aksara, 1995.

Perpustakaan RI, UU RI No. 43 Tahun 2007.

Prasetijo, Ristiyanti dan John Ihalauw, Perilaku Konsumen, Yogyakarta: Andi, 2005. 
Priyanto, Ida Fajar, "Layanan Pemakai yang Berkualitas: Suatu Gagasan”, Media Informasi, Tahun XI, Maret 1997.

Pudjiono, "Membangun Citra: Perpustakaan Perguruan Tinggi di Indonesia Menuju Perpustakaan Bertaraf Internasional,, http://www.lib.ui.ac.id/files/pudjiono.pdf, diakses pada 28 Maret 2016.

Sinaga, Dian, Mengelola Perpustakaan Sekolah, Jakarta: Kreasi Media Utama, 2007.

Sulistiyo, Basuki, Pengantar Ilmu Perpustakaan, Jakarta: Gramedia, 1991.

Sutarno, N.S., Perpustakaan dan Masyarakat, Jakarta: Sagung Seto, 2006.

Tjiptono, Fandy, Strategi Pemasaran, Yogyakarta: Andi Offset, 2001.

Wiranto, F.A., dkk., Perpustakaan Menjawab Tantangan Jaman, Semarang: Penerbit Universitas Katolik Soegijapranata bekerja sama dengan Perpustakaan Daerah Jawa Tengah, 1997. 